tecting deterioration but a separate evaluation by the research team showed that at least $74 \%$ of the patients who had been deemed to have relapsed had an increase of florid symptoms. Though one-third of the patients in our sample had florid symptoms when they entered the trial their condition was stabilized at the time. When switched to placebo $83 \%$ of these increased the number of florid symptoms (table VII). The social behaviour of many patients on placebo deteriorated and put additional strain on their relatives (Stevens, 1973), but in most cases it was associated with an exacerbation of schizophrenic symptoms. We therefore conclude that fluphenazine decanoate has a powerful effect in preventing and ameliorating both schizophrenic symptoms and deterioration of behaviour and social functioning.

We have stated that we cannot accept the $8 \%$ relapse rate of our experimental group at face value. Ninety-five per cent. of our sample had been established on treatment more than three months and most more than a year, so that patients who had been negative responders, relapsed or lapsed from treatment would have been omitted from the sample. Thus the proportion of chronic schizophrenics who relapsed and began treatment with fluphenazine decanoate but were unlikely to remain well-controlled for a year might be expected to be more than $30 \%$, in contrast to patients well established on treatment, of whom only $8 \%$ relapsed during nine months in this trial.

It is noteworthy that $89 \%$ of patients entering our trial received just one $25-\mathrm{mg}$ injection of fluphenazine decanoate monthly. Some centres give much higher doses, but these findings suggest that low doses are effective in most cases.

This study has not touched on the problems of the chronic disabilities of these patients. With the greater control of florid symptoms which treatment provides the management of residual disability will become an increasing problem, because of the growing number of chronic patients returning to live in the community.

We gratefully acknowledge the active co-operation and participation of Sisters $M$. Lodge and $M$. Green and the nursing and secretarial staff at St. Francis and St. Olave's hospitals who administered the medication, recorded detailed observations, and kept us informed of changes in the patients' clinical status. We are indebted to Miss C. Durston and Mrs. J. Codling for helping to co-ordinate the study and to Drs. D. Bennett, A. Isaacs, and A. J. Oldham for allowing us to put their patients in the trial. We also wish to thank E. R. Squibb and Sons, Ltd., who generously provided supplies of fluphenazine decanoate and placebo.

\section{References}

Bankier, R. G., Pettit, D. E., and Bergan, B. (1968). Diseases of the Nervous System, 29, 56.

Blackweil, B., and Shepherd, M. (1968). Lancet, 1, 968.

Brown, G. W., and Birley, J. L. T. (1970). British Эournal of Psychiatry, 116, 327.

Bucci, L., Fuchs, M., Simeon, J., and Fink, M. (1970). Diseases of the Nervous System, 31, Suppl., p. 28.

Crumpton, N. (1968). In Treatment of Mental Disorders in the Community, ed. G. R. Daniel and H. T. Freeman, p. 15. Baltimore, Williams and Wilkins.

Daniel, G. R. (1968). British fournal of Social Psychiatry, 2, 167.

Denham, J., and Adamson, L. (1971). Acta Psychiatrica Scandinavica, 47, 420.

Engelhardt, D. M., and Freedman, N. (1970). Social Psychiatry, ed. Ari Kiev, ch. 11. London, Routledge and Kegan.

Finney, D. J., Latscha, R., Bennet, B. M., and Hsu, P. (1963). Tables for Testing Significance in $2 \times 2$ Contingency Tables. London, Cambridge University Press.

Guidice, J., Okun, R., and Clark, W. (1970). Recidivism with long-acting injectable fluphenazine. Talk to 7 th congress of the Collegium of International Neuro-Psychopharmacologists. Prague, 1970.

Goldberg, S. C., Mattson, N., Cole, J. O., and Klerman, G. L. (1967). Archives of General Psychiatry, 16, 107.

Haider, I. (1968). British fournal of Psychiatry, 114, 837.

Johnson, D., and Freeman, J. (1972). Practitioner, 208, 395.

Kinross-W right, J., and Charalampous, K. D. (1965). International fournal of Neuropsychiatry, $1,66$.

Kurland, A. A., and Richardson, J. H. (1966). Psychopharmacolgia, 9, 320.

Lasky, J., et al. (1962). Diseases of the Nervous System, 23, 698

eff, J., and Vaughn, C. (1972). In Evaluating a Community Psychiatric Service, ed. J. K. Wing, A. M. Hailey, ch. 17. London, Oxford University Press.

Leff, J., and Wing, J. K. (1971). British Medical fournal, 3, 599.

Oldham, A. J. (1969). British fournal of Psychiatry, 115, 465.

Rasmussen, O. S. (1970). Acta Psychiatrica Scandinavica, 46, 311

Ravaris, C. L., Weaver, L. A., and Brooks, G. W. (1965). Diseases of the Nervous System, 26, 33.

Stevens, B. (1972). Psychological Medicine, 2, 17.

Stevens, B. (1973). Psychological Medicine. In press.

Van Praag, H. M., et al. (1970). Psychiatria, Neurologia, Neurochirurgia, 73,

Wing, J. K., Wing, L., Griffiths, D., and Stevens, B. (1972). Chap. 19 In Evaluating a Community Psychiatric Service, ed. J. K. Wing, A. M. Hailey, Ch. 19. London, Oxford University Press.

Wing, J. K., Sartorius, N., and Cooper, J. (1973). To be published.

\title{
Secondary Hyperparathyroidism in Patients with Endemic Skeletal Fluorosis
}

\author{
S. P. S. TEOTIA, MOHINI TEOTIA
}

British Medical fournal, 1973, 1, 637-640

\section{Summary}

Investigation of 20 patients with skeletal fluorosis showed that five had clear evidence of secondary hyperparathyroidism. The hyperactivity of the parathyroid glands in skeletal fluorosis in the presence of decreased solubility of the bone mineral (fluoroapatite) strongly suggests that it is a compensatory attempt to maintain a normal extracellular ionized calcium equilibrium. Further study of the parathyroid glands and of bone lesions in skeletal fluorosis is in progress.

Department of Human Metabolism, L.L.R.M. Medical College, Murut, U.P., India

S. P. S. TEOTIA, M.D., Professor of Human Metabolism and Head of

Department
MOHINI TEOTIA, M.D., D.C.H., Senior Research Officer, Indian Council of Medical Research

\section{Introduction}

During the past four years we have noticed that patients with endemic skeletel fluorosis often show radiological bone changes, such as coarse cystic trabeculation and sub periosteal phalangeal resorption. These observations, coupled with reports in the literature of resorption cavities in animal experimental fluorosis (De Senar Clens, 1941; Rockert and Sunzel, 1960; Rockert, 1963) suggested to us the possibility of hyperactivity of the parathyroid glands in patients with skeletal fluorosis. The present study was therefore undertaken to investigate the pathogenetic role of the parathyroids in patients with skeletal fluorosis.

\section{Subjects and Methods}

Twenty patients (17 men and 3 women) aged 42 to 68 years with proved endemic skeletal fluorosis were investigated for 
parathyroid hyperfunction. All belonged to a low socioeconomic class and had lived since birth in an endemic fluorosis area-namely, the Madheya Khan Ka Purwa in the district of Rai Bareli, Uttar Pradesh, India. Radiological changes suggestive of hyperparathyroidism were observed in only five patients, and subsequent investigations were therefore confined to these cases.

Laboratory investigations included plasma calcium, phosphorus, and alkaline phosphatase; blood urea; creatinine clearance, phosphate clearance, tubular reabsorption of phosphate, urinary calcium, and urinary fluoride; and chemical analysis of the bone ash for calcium, phosphorus, and fluoride. Faecal excretion of fat was estimated in each patient on a sixday collection. Skeletal and dental radiographs and biopsy specimens of the iliac crest were studied. The fluoride content of the bone, drinking water, and urine samples was determined spectrophotometrically using zirconium dye complex, as detailed by Megregian (1954).

\section{Observations and Results}

A summary of the laboratory investigations is given in table $I$.

TABLE I-Laboratory Investigations* in Patients Studied

\begin{tabular}{|c|c|c|c|c|c|c|c|c|c|}
\hline \multirow[b]{2}{*}{$\begin{array}{l}\text { Case } \\
\text { No. }\end{array}$} & \multicolumn{3}{|c|}{ Plasma } & \multirow{2}{*}{$\begin{array}{c}\text { Crea- } \\
\text { tine } \\
\text { Clear-- } \\
\text { ance } \\
(\mathrm{ml} / \mathrm{min} / 1\end{array}$} & \multirow{2}{*}{$\begin{array}{c}\text { Phos- } \\
\text { phate } \\
\text { Clear- } \\
\text { ance } \\
1.73 \mathrm{~m}^{2} \text { ) }\end{array}$} & \multirow{2}{*}{$\begin{array}{c}\text { Tubu- } \\
\text { lar Re- } \\
\text { absorp- } \\
\text { tion of } \\
\text { phos- } \\
\text { phate } \\
(\%)\end{array}$} & \multirow{2}{*}{$\begin{array}{l}\text { Urine } \\
\text { Cal- } \\
\text { cium } \\
\text { (mg/ } \\
\text { Day) }\end{array}$} & \multirow{2}{*}{$\begin{array}{c}\text { Urine } \\
\text { Fluor- } \\
\text { ide } \\
\text { (p.p.m./ } \\
\text { Day) }\end{array}$} & \multirow[b]{2}{*}{$\begin{array}{c}\text { Faecal } \\
\text { Fat } \\
(\mathrm{g} / \mathrm{Day})\end{array}$} \\
\hline & $\underset{\substack{\text { Cal- } \\
\text { cium } \\
(\mathrm{mg} / 100}}{\mid}$ & $\begin{array}{c}\text { Phos- } \\
\text { phorus } \\
\text { (mg/100 } \\
\text { ml) }\end{array}$ & $\begin{array}{l}\text { Alk. } \\
\text { Phos- } \\
\text { phatase } \\
\text { K.A. } \\
\text { units }\end{array}$ & & & & & & \\
\hline $\begin{array}{l}1 \\
2 \\
3 \\
4 \\
5\end{array}$ & $\begin{array}{r}9 \cdot 2 \\
11 \cdot 2 \\
9 \cdot 5 \\
10 \cdot 8 \\
9 \cdot 7\end{array}$ & $\begin{array}{l}4 \cdot 3 \\
3.0 \\
3 \cdot 6 \\
3 \cdot 5 \\
4 \cdot 5\end{array}$ & $\begin{array}{l}80 \\
60 \\
34 \\
48 \\
26\end{array}$ & $\begin{array}{l}126 \\
140 \\
135 \\
122 \\
126\end{array}$ & $\begin{array}{l}20 \\
36 \\
27 \\
32 \\
25\end{array}$ & $\begin{array}{l}75 \\
64 \\
75 \\
70 \\
82\end{array}$ & $\begin{array}{l}65 \\
85 \\
60 \\
50 \\
65\end{array}$ & $\begin{array}{l}4.8 \\
4.8 \\
3.4 \\
3.0 \\
3.2\end{array}$ & $\begin{array}{l}1.8 \\
3.2 \\
3.8 \\
2.7 \\
4.5\end{array}$ \\
\hline
\end{tabular}

"Urinary amino-acid chromatograms showed normal "glycine" patterns. Blood urea ranged from 18 to $28 \mathrm{mg} / 100 \mathrm{ml}$. Calcium was corrected for specific gravity of the plasma.

Radiological Changes.-Diagnostic radiological features were observed in each patient and included osteosclerosis, particularly of the spine pelvis and thorax irregularly outlined osteophytes; periosteal bone formation; irregular exostoses; and calcification of ligaments, interosseous membrane, and muscular attachments. Appearances characteristic of hyperparathyroidism where present in all the patients. These included (1) subperiosteal resorption in the phalanges, (2) erosions or loss of the lamina dura, and (3) coarse and cystic trabeculations, metaphyseal erosions, and thinning of the cortex particularly in the pelvis knees and hands (figs. 1 and 2).

Bone Histology.-Undecalcified and decalcified sections of the bone obtained from the iliac crest by open biopsy were studied histologically in all cases (fig. 3). The compact bone showed poorly formed haversian systems and disordered lamellar orientation of the bone. Irregular deposits of osteoid tissue were seen among the bone trabeculae, which were thick at places and contained an excess of calcium. Osteoclastic resorption and irregular erosions in the edges of the bone trabeculae were observed in all five cases. An increase in the periosteocytic surface resorption area was seen in all the specimens and strongly suggested the parathyroid overactivity (table II).

Fluoride in Drinking Water.-Twenty samples of water were analysed from four wells located at different places in the endemic area and showed a fluoride concentration of 10.313.5 p.p.m. The mean intake of fluoride from water alone by each patient was. $25 \mathrm{mg} /$ day, and when it is realized that the same water had been used for processing and cooking the food the intake becomes still larger.

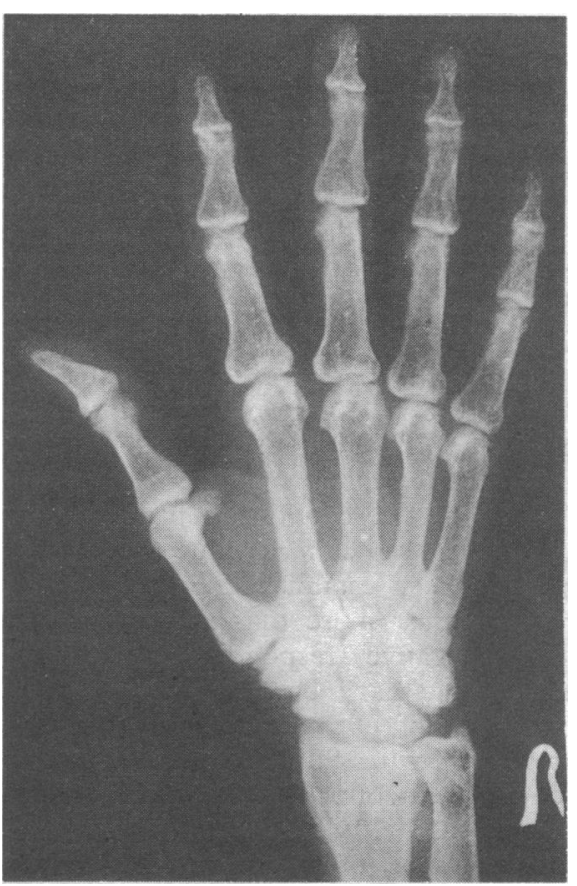

FIG. 1-Case 2. Radiograph showing increased density, coarse trabeculae, and'cortical erosions of the phalanges, especially of the fifth finger. Crippling fluorosis with tertiary hyperparathyroidism. High plasmacalcium (11 mg/100 $\mathrm{ml})$. Parathyroid adenoma found on exploration of the neck.

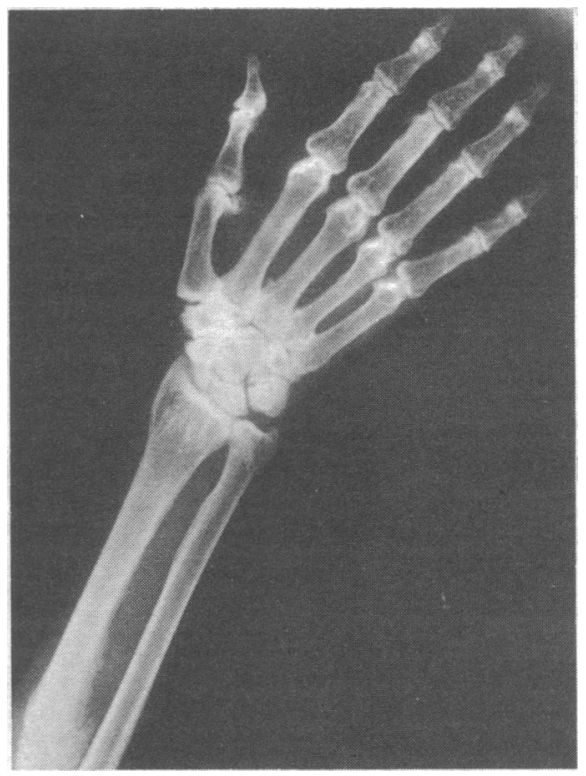

FIG. 2-Case 2. Radiograph taken eight weeks after removal of parathyroid adenoma showing healing of cortical erosions in the phalanges. Forearm shows calcification of the interosseous membrane as a diagnostic feature of skeletal fluorosis.

TABLE II-Quantitative Histology of Iliac Bone Specimens

\begin{tabular}{c|c|c|c|c}
\hline $\begin{array}{c}\text { Case } \\
\text { No. 7 }\end{array}$ & $\begin{array}{c}\text { Bone Surface } \\
\text { with Osteoid } \\
(\%)\end{array}$ & $\begin{array}{c}\text { Osteoid Surface } \\
\text { with a Calcifica- } \\
\text { tion Front (\%) }\end{array}$ & $\begin{array}{c}\text { Total Bone Sur- } \\
\text { face with Re- } \\
\text { sorption Lacunae } \\
\text { (\%) }\end{array}$ & $\begin{array}{c}\text { Periosteocvic } \\
\text { Surface Resorp- } \\
\text { tion Area ( } \mu^{2} \text { m) }\end{array}$ \\
\hline 1 & 26 & 92.5 & 23.8 & 82.5 \\
2 & 30 & 88.0 & 18.4 & 77.0 \\
3 & 25 & 82.3 & 16.5 & 68.7 \\
4 & 23 & 89.0 & 14.3 & 65.8 \\
5 & 23.5 & 95.0 & 16.2 & 74.2 \\
\hline Normal & 16 & 80 & 4.8 & 55.0 \\
\hline
\end{tabular}




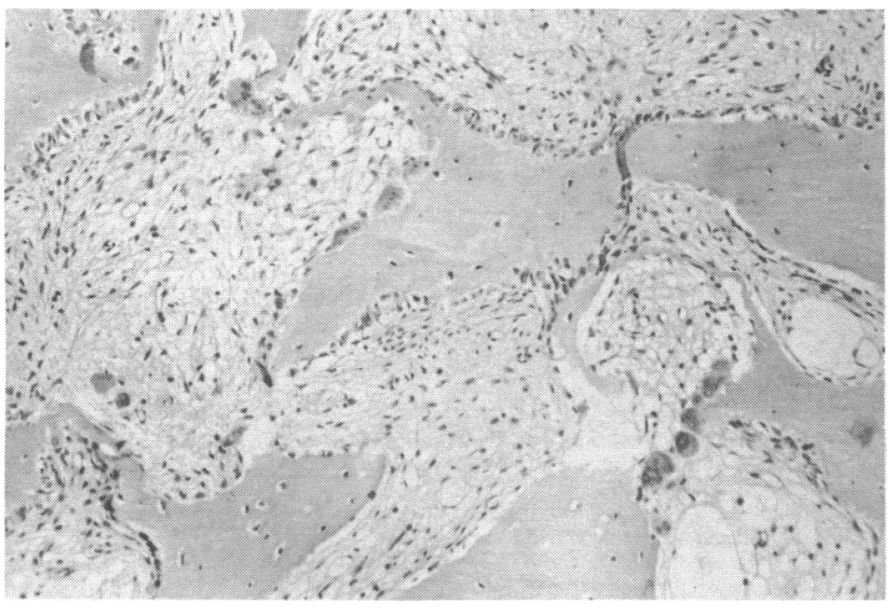

FIG. 3-Case 2. Histological picture of iliac crest biopsy specimen showing irregular osteoclastic resorption of the bone trabeculae and increased periosteocytic osteolysis suggestive of hyperparathyroidism. (x 292.)

\section{Discussion}

All the five patients were men aged 42 to 60 years and had symptoms that had ranged in duration from 5 to 11 years. Clinical findings were similar to those reported by us previously (Teotia et al., 1969) and included mottled discolouration of the teeth, skeletal pains, restricted and painful joint movements, backache, stiffness and rigidity of the spine, and an inability to close the fists. One patient (case 2) had generalized forward flexion, fixed chest with minimal expansion, grossly limited movements of the spine, and flexion deformities at the hips and knees suggesting crippling fluorosis.

The laboratory investigations (table I) showed extremely high plasma alkaline phosphatase, increased phosphate clearance, and decreased tubular reabsorption of phosphate suggestive of parathyroid hyperfunction. Each patient showed an increased urinary excretion of fluoride and a low urinary calcium. Chemical analysis of the iliac bone showed an excess of calcium and fluoride (table III).

TABLE III-Bone Composition (Ileum) per $100 \mathrm{~g}$ Dry Fat-free Bone Ash*

\begin{tabular}{c|c|c|c}
\hline $\begin{array}{c}\text { Case } \\
\text { No. }\end{array}$ & $\begin{array}{c}\text { Calcium } \\
(\mathbf{g})\end{array}$ & $\begin{array}{c}\text { Phosphorus } \\
(\mathbf{g})\end{array}$ & $\begin{array}{c}\text { Fluoride } \\
\text { (mg) }\end{array}$ \\
\hline 1 & $13 \cdot 2$ & 5.3 & 585 \\
2 & 12.0 & $5 \cdot 0$ & 420 \\
3 & 13.2 & $5 \cdot 0$ & 475 \\
4 & 11.8 & $5 \cdot 2$ & 378 \\
5 & 12.5 & 4.8 & 265 \\
\hline
\end{tabular}

- Figures obtained from a person from a non-fluorotic area were calcium $10.8 \mathrm{~g}$, phosphorus $4.9 \mathrm{~g}$, and fluoride $30 \mathrm{mg}$.

Skeletal radiographs showed typical changes of both fluorosis and hyperparathyroidism and included a generalized increase of bone density, calcification of interosseous membrane, and subperiosteal resorption of the phalanges (figs. 1 and 2) and coarse cystic trabeculations. Dental $x$-ray films showed resorption of the alveolar bone around the roots of the teeth with erosion or loss of lamina dura in all five cases.

The histological bone changes suggestive of hyperparathyroidism osteoclastic erosion of the bone trabeculae and increased periosteocytic surface resorption area, were observed in each patient (table II, fig. 3). Radiographically and histologically the patients showed features of a combination of fluorosis and hyperparathyroidism. All the patients had adequate calcium and vitamin $D$ in the diet and none showed renal disease or intestinal malabsorption (table $\mathrm{I}$ ).

It is of note that in case $\mathbf{2}$ (table I) suspiciously high plasma calcium and low plasma phosphorus levels were recorded, which suggest that the patient was in the course of develop? ing tertiary hyperparathyroidism in the sense described by Davis et al. (1968). Subsequently parathyroid hyperplasia was discovered at operation and the right upper parathyroid gland, which showed an adenoma weighing $3.8 \mathrm{~g}$, was removed (fig. 4). Presumably this was a possible case of tertiary hyperparathyroidism in which the adenoma arose after long-standing hyperplasia as a result of excessive fluoride intake.

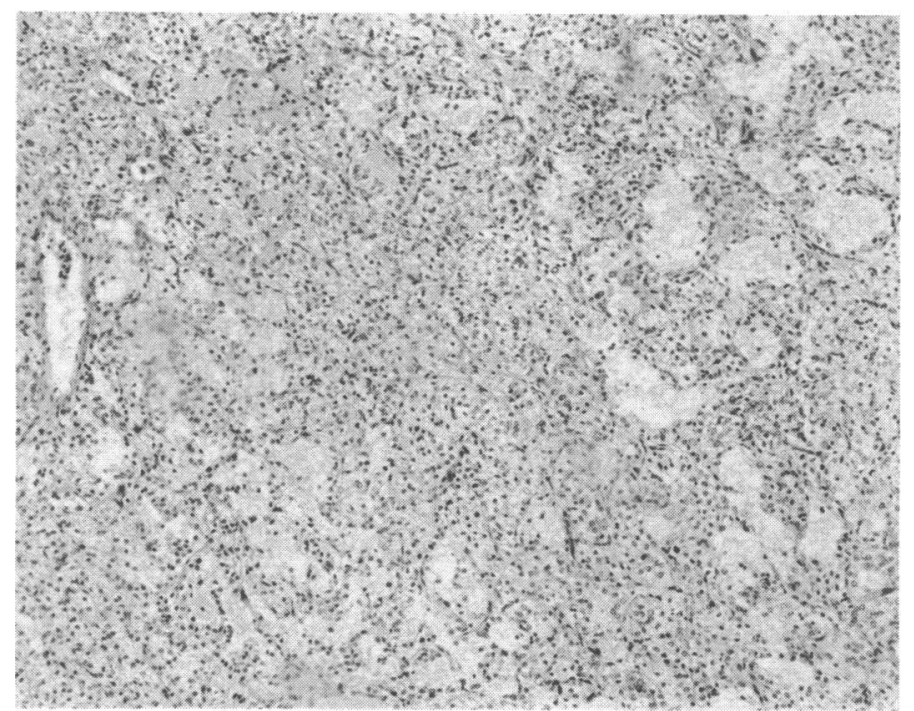

FIG. 4-Case 2. Parathyroid adenoma composed of masses of chief cells. Oxyphil cells were uncommon and the other three glands showed secondary hyperplasia. ( $x$ 70.)

Reports in the literature on parathyroid hyperfunction in human skeletal fluorosis are sparse. Nichols et al. (1965) reported on a patient with multiple myelomatosis treated with fluoride who subsequently developed radiological evidence of fluorosis and a metabolic pattern indistinguishable from that seen in patients with hyperparathyroidism. Bernstein and Cohen (1967) confirmed parathyroid hyperplasia at operation in three patients with osteoporosis who had received fluoride for six months to a year. Teotia et al. (1971) reported radiological changes suggestive of hyperparathyroidism secondary to fluorosis in an 11-year-old patient with endemic skeletal fluorosis.

In a thorough experimental study Faccini and Care (1965) observed overactivity of the parathyroid glands in a fluorotic sheep; this they demonstrated by an electron-microscopical study of the parathyroid glands and a concomitant immunoassay of the amount of circulating parathyroid hormone, which was found to be as much as five times higher than resting and control levels. The serum calcium remained within normal limits.

The mechanisms leading to the hyperfunction of the parathyroid glands in skeletal fluorosis are not clear. The experimental evidence that fluoride containing bone from other species can resist resorption was provided by Havivi and Guggenheim (1966), who found that fluoride bone from mice had a reduced ${ }^{45} \mathrm{Ca}$ release compared with control bone when the animals were given injection of parathyroid extract for two weeks. Berry and Trillwoid (1963) and Proffit and Ackerman (1964) reported that when the fluoride toxicity is not severe enough to cause a generalized cellular depression then a compensatory mechanism which is mediated through the parathyroids probably develops to overcome the physicochemical properties of bone apatite crystals.

Crystallographic studies have shown that the apatite crystals in fluorotic bone are of a larger size (Zipkin et al., 1963) than in normal bone. This improvement in crystal texture is 
accompanied by the diminished solubility and mobility of the bone salt. The fluoroapatite crystals, therefore, are more stable and less reactive in surface exchange reactions, since larger crystals offer less surface area for a given weight of bone. It may therefore be assumed that these changes increase the resistance of bone to the actions of the parathyroid hormone and may cause lowering of the plasma ionized calcium, so stimulating the compensatory parathyroid activity.

However, it seems unlikely that the reduced resorption of fluoride bone alone is the factor exciting parathyroid stimulation, particularly in the light of certain animal experiments. Yates et al. (1964) showed evidence of parathyroid stimulation on a short-term basis using intraperitoneal lavage in rats. Faccini (1969) performed immunoassay of parathyroid hormone in sheep and demonstrated a significant increase in circulating hormone levels only a week after starting fluoride administration. The possibility, therefore, that fluoride might induce secondary hyperparathyroidism by interfering with the calcium equilibrium between bone and serum by accelerating crystal growth or producing a more rapid ion exchange has to be considered. We also feel that further investigations to exclude the direct effect of fluoride on the parathyroids are necessary.

We are most grateful to Professor C. E. Dent, University College Hospital Medical School, London, for his advice and helpful criticism of the manuscript, and to Miss Susan Heels and Mr. Robert R. Burns, also of University College Hospital Medical School, for their invaluable technical help.
Addendum.- Since preparing this manuscript we have determined serum immunoreactive parathyroid hormone levels in our patients and found the expected high levels of $1,250,2,800,1,0751,050$, and $1,225 \mathrm{pg} / \mathrm{ml}$ respectively (in the assay used parathyroid hormone was unmeasurable in normal subjects). Immunoreactive parathyroid hormone levels correlated positively with the biochemical, radiological, and histological findings in all five cases.

\section{References}

Berry, R. J., and Trillwood, W. (196?). British Medical fournal, 2, 1064. Bernstein, D., and Cohen, P. (1967). Fournal of Clinical Endocrinology and Metabolism, 27, 197. De Senarclens (1941). Contribution à l'etude de l'osteopathie fluorique.
M.D. thesis, University of Geneva. Davies, D. R., Dent, C. E., and Watson, L. (1968). British Medical Journal,
2, 395 .

Faccini, J. M., and Care, A. D. (1965). Nature, 207, 1399.

Faccini, J. M. (1969). Calcified Tissue Research, 3, 1.

Havivi, E., and Guggenheim, K. (1966). Fournal of Endocrinology, 36, 357. Megregian, S. (1954). Annales de Chimie, 26, 1161

Megregian, S. (1954). Annales de Chimie, 26, 1161. (1965). Glands; Ultrastructure, Secretion and Function, ed. P. J. Gaillard and Glands; Ultrastructure, Secretion and Function, ed. P. J. Gaillar
R. V. Talmage, p. 243. Chicago, University of Chicago Press.

R. V. Talmage, p. 243. Chicago, University of Chicago

Proffit, W. D., and Ackerman, J. L. (1964). Science, 146, 932.

Rockert, H., and Sunzel, H. (1960). Experientia, 16, 155.

Reckert, H. (1963). Acta Pathologica et Microbiologica Scandinavica, 49, 32.

Teotia, M., Teotia, S. P. S., and Kunwar, K. B. (1971). Archives of Disease in Childhood, 46, 686 .

Yates, C., Doty, S., and Talmage, R. V. (1964). Proceedings of the Society for Experimental Biology and Medicine, 115, 1103. Zipkin, I., Schraer, R., Schraer, H., and Lee, W. A. (1963). Archives of
Oral Biology, 8, 119.

\title{
Fibrinolysis in Cholestatic Jaundice
}

\author{
A. JEDRYCHOWSKI, \\ SHEILA SHERLOCK \\ P. HILLENBRAND, A. B. AJDUKIEWICZ, S. P. PARBHOO,
}

British Medical fournal, 1973, 1, 640-642

\section{Summary}

The fibrinolytic system was studied in primary biliary cirrhosis (16 patients) and large bile duct obstruction (10 patients, nine of whom had carcinoma). Plasma fibrinolysis (plasminogen activator activity) was decreased and fibrinogen increased in both groups of patients, particularly in those with large duct obstruction. These changes were related to the degree of cholestasis. Plasminogen activator activity was inversely related to serum triglyceride levels in patients with primary biliary cirrhosis. Urokinase inhibitors were decreased in both groups and antiplasmins increased in patients with large duct obstruction; fibrin/fibrinogen degradation products were normal in primary biliary cirrhosis and moderately increased in large duct obstruction. None of these fibrinolytic indices was related to the degree of cholestasis. Fibrinolytic activity and fibrinogen returned almost to normal levels after palliative surgery in the

Department of Medicine, Royal Free Hospital, London WC1X 8LF A. JEDRYCHOWSKI, M.D., Research Fellow (Present address: Instytutu Medycyny, Wewnetrznej, ul. Kopernika 15, Krakow, Poland)

P. HILLENBRAND, M.B., M.R.C.P., Research Fellow (Present address: Department of Gastroenterology, The London Hospital, London E1 1BB) A. B. AJDUKIEWICZ, M.B., M.R.C.P., Research Fellow (Present address: Department of Medicine, Ahmadu Bello University, Zaria, Nigeria)

S. P. PARBHOO, PH.D., F.R.C.S., Lecturer (Present address: Department of Surgery, Frenchay Hospital, Bristol)

SHEILA SHERLOCK, M.D., F.R.C.P., Professor of Medicine three patients with large duct obstruction who were studied. The decreased plasma fibrinolysis and increased fibrinogen may be due to altered lipid metabolism in cholestatic jaundice. In patients undergoing surgery for large duct obstruction there may be an increased risk of thrombosis.

\section{Introduction}

Little is known about fibrinolysis in cholestatic jaundice. Ratnoff (1949), Nilehn and Nilsson (1964), and van de Loo and Schmiesing (1965) found normal fibrinolytic activity in patients with this condition. Few patients were studied, however, and the methods used were usually designed to detect normal or increased rather than decreased fibrinolysis. We therefore investigated fibrinolysis in two groups of patients: one group with primary biliary cirrhosis and the other with large bile duct obstruction.

\section{Patients and Controls}

Sixteen patients (aged 35-66 years) with primary biliary cirrhosis were studied. The diagnosis was based on clinical, immunological, and histological criteria (Scheuer, 1968; Sherlock, 1968). There were 10 patients (aged 28-62 years) with obstruction to large bile ducts; nine had carcinoma of the pancreas or bile ducts and one a stricture of the common bile duct. The control group (12 men and nine women, aged 21-62 years) were healthy medical and laboratory personnel. 